\title{
Capital Structure and its Impact on Financial Performance in Insurance Companies of Nepal
}

\author{
Bhupal Jaishi*
}

DOI: https://doi.org/10.3126/jnbs.v13i1.34708

\begin{abstract}
The paper attempts to examine the relationship between capital structure and the financial performance of Nepalese insurance companies. Return on assets and earnings per share are the dependent variables. Independent variables are total debt ratio, equity to total assets ratio, size, liquidity and tangibility. This paper uses descriptive as well as causalcomparative research design to examine the general structure of capital structure and financial performance and their relationship. The data were collected from annual reports of listed insurance companies in Nepal. The study is based on 84 observations from 14 insurance companies of Nepal from 2013/14 to 2018/19. The regression models are estimated to test the effect on financial performance variables i.e. return on assets and earnings per share. The result shows that insurance companies having a high debt ratio have better financial performance. An increase in debt ratio and tangibility increase return on assets and an increase in equity, size and liquidity decrease return on assets in the industry. The impact of the debt ratio and tangibility on earning per share is positive and there is the negative impact of equity, size and liquid ratio on earning per share. The major conclusion of this study is that total debt ratio, equity to total assets ratio, leverage, size, liquidity and tangibility are the significant factors in determining the financial performance of Nepalese insurance companies. The insurance companies of Nepal interested to increase financial performance can increase their total debt ratio and tangible assets and decrease equity, firm size, and liquidity ratio.
\end{abstract}

Keywords: Capital structure, financial performance, liquidity, size, tangibility

\footnotetext{
*Mr. Jaishi is as Assistant Professor at Faculty of Management, Prithvi Narayan Campus, Tribhuvan University

Email: bpl.jaishi@gmail.com
} 


\section{INTRODUCTION}

The financial sector is one of the key components of economic development. A strong financial system promotes investment and allocates resources efficiently. A well evolved and developed insurance industry provides a long term fund for economic development (Agiobenebo \& Ezirim, 2002). The importance of the insurance sector in developed, as well as developing countries, has been increased as it contributes significantly to economic growth and national wealth. (Kaya, 2015). In Nepal, insurance companies are classified into life insurance, non-life insurance, and reinsurance companies.

The study of capital structure attempts to explain the mix of securities and financing sources used by corporations to finance real investment (Myers, 1977). Components of capital structure are equity capital, debt capital, and hybrid capital. Capital structure is the way a firm finance it is assets across the blend of debt, equity, or hybrid securities (Saad, 2010). Capital structure decision directly influences the investment decision and operational decision of the corporation. Capital structure decision is one of the major financial decisions to be determined at an optimum level as it influences the investment and operational decision of the business. The goal of modern business organizations is to maximize the wealth or value of that firm (Modigliani \& Miller, 1958, 1963). The capital structure of a firm is related to the ability of the firm to meet the needs of its stakeholders. Modigliani and Miller (1958) presented the strong argument that capital structure is irrelevant to the value of the firm. Modigliani and Miller (1963) revised the original argument and presented the argument for relevancy of capital structure on the market value of the firm and justified that the market value of the firm is positively related to the amount of long term debt used, in the presence of corporate income tax and the cost of capital. Companies that do not formally plan their capital structures are likely to face unconformable difficulties in raising capital on favorable terms in the long-run (Wippern, 1966).

The financial performance of a firm can be analyzed in terms of profitability, dividend growth, sales turnover, assets base, capital employed among others. The financial performance of insurance companies is measured as revenue from premium, income through underwriting activities, returns on assets, earnings per share, and return on equity. These measures are further divided into profit performance and investment performance measures. The relationship between capital structure and financial performance is one of the debatable issues in both developed and developing countries.

\section{LITERATURE REVIEW}

Saeedi and Mahmoodi (2011) examined the relationship between capital structure and firm performance of 320 firms listed on the Tehran Stock Exchange. The empirical research concludes that there is a negative relationship between capital structure and return on assets; on the other hand, there is no significant relationship between capital structures on return on 
equity. Ahmed, Ahmed, and Ahmed (2010) concluded that assets tangibility and firm size have a significant and positive relationship with debt ratio whereas there is a significant negative relationship between liquidity and debt ratio. Opoku, Audu, and Anarfi, (2013) studied the impact of capital structure on profitability in the Ghanaian Stock Exchange, the study reveals that there is a negative relationship between total debt ratio and profitability among the listed banks. The bank size has a negative relationship with profitability.

Taub (1975) found that the return to the firm, long term rate of interest, and size of the firm revealed a positive influence on the firm's debt-equity ratio. Zeitun and Tian (2007) showed that all the capital structure variables including short term debt, total debt, long term debt, and total equity have a significantly negative impact on firm performance. Yahyazadehfar, Shams, and Larimi, (2010) found a negative relationship between the debt ratio of the company and assets' structure, profitability, and market value to book value. Saeedi and Mahmoodi (2011) showed that EPS is significantly and positively associated with capital structure. However, ROA is negatively associated with capital structure. Pouraghajan, Ramezani, Mansourinia, Emmagho, and Majd (2012) found that there is a significant negative relationship between debt ratio and financial performance of companies, and a significant positive relationship between asset turnover, firm size, asset tangibility ratio, and growth opportunities with financial performance measures. Dogan (2013) exhibits that the financial leverage ratio negatively affects profitability as measured by ROA whereas firm size has a positive impact on the firm's profitability. Idode, Adeleke, Ogunlowore, and Ashogbon, (2014) examined that capital structure has a significant positive influence on profitability. Chechet and Olayiwola (2014) reveal that the debt ratio is negatively related to profitability and equity has a significant and positive impact on firm performance. Kazempour and Aghaei (2015) showed a significant positive relationship between capital structure and firm performance.

In the context of Nepal, few studies have been carried out on the relationship between capital structure and the financial performance of Nepalese firms. Poudel (1994) observed that size and growth were positively related to leverage and risk, profitability, and assets structure were negatively related to leverage. Basnet (2015) concluded that standard determinants of banks' capital structure do affect the market leverage of the banks and capital structure theories- trade-off and the pecking order is complementary for the Nepalese commercial banks. Bhattarai (2016) concluded that capital structure significantly negatively affects the firm performance of Nepalese manufacturing companies. Maharjan (2017) found that long term debt to equity ratio, total debt to equity ratio, bank size, and liquidity position is negatively related to firm performance.

However, there is a positive relationship between credit risk with firm performance. Bajracharya (2019) concluded that liquidity has a negative relationship with the return on assets of the joint venture, public, and private banks. Pradhan and Shrestha (2015) found that 
long term debt to total assets, total debt to total assets, debt to equity ratio, and interest coverage ratio are the major variables with a significant impact on Nepalese banks' profitability. Most of the Nepalese studies are concentrated on examining the impact of capital structure on the financial performance of commercial banks but the study on the insurance industry needs to be addressed in the Nepalese context. This study therefore addresses the research gap on the same.

\section{METHODOLOGY}

This paper has employed descriptive and causal-comparative research designs. The descriptive research design has been adopted for fact-finding and adequate information gathering about the fundamental issues associated with capital structure and financial performance variables of Nepalese insurance companies. It explains the real and actual conditions, situations, and facts. Causal-comparative research design has been used to establish the cause and effect relationship between capital structure and financial performance of Nepalese insurance companies. More specifically, the paper analyzed the impact of total debt ratio (TDR), equity to total assets (ETA), Firm size (SIZE), liquidity (LQ), assets tangibility (TAN) on return on assets (ROA) and earnings per share (EPS).

Descriptive statistics, correlation, and regression methods of analysis are used in the study. The descriptive statistics contain mean, standard deviation, minimum and maximum values of variables which are used to explain the characteristics of sample companies. The correlation analysis is used to measure the direction and magnitude of the relationship between dependent and independent variables. The regression analysis is used to find out the influence of the independent variable over the dependent variable solely and combined with other variables. Those data were analyzed with the help of SPSS version 20.0 and the MsExcel office package. The study is primarily based on secondary data. The population of the study comprises all the 40 insurance companies in Nepal. The sample of the study is 14 insurance companies selected based on seven life insurance companies having 10 years of establishment and seven non-life insurance companies using random sampling A total of 84 observations are used in the study. The study period is six years from the fiscal year 2013/14 to $2018 / 19$. Appendix I presents the number of insurance companies selected for the study.

\section{Model Specification}

The econometric models employed in this study tries to analyze the relationship between capital structure and financial performance. The following regression model is used in this study to examine the empirical effect of capital structure on the financial performance of Nepalese insurance companies. The following models have been used to examine the empirical effect based upon previous studies of Berger (1995); Rajan and Zingales (1995); Sunder and Myers (1999); Zeitun and Tian (2007); Goyal (2013); Singh and Bagga (2019). 
From the conceptual framework the function of dependent variables (i.e. financial performance) takes the following form:

Financial performance $=f($ TDR, ETA, SIZE, LQ, TAN $)$

More specifically, the given model has been segmented into the following models:

\section{Model 1}

In this model, the dependent variable is the return on assets (ROA) indicated by the percentage of net income to total assets. Total debt ratio, equity to total assets, firm size, liquidity ratio, and asset tangibility are independent variables that are tested on return on assets. The model is presented as follows:

$$
R O A=\beta_{0}+\beta_{1} T D R+\beta_{2} E T A+\beta_{3} S I Z E+\beta_{4} L Q+\beta_{5} T A N+\beta_{6} E P S+e
$$

\section{Model 2}

In this model, the dependent variable is earnings per share (EPS) indicated by net income to the number of equity shares, in rupees per share. Total debt ratio, equity to total assets, firm size, liquidity ratio, and asset tangibility are independent variables that are tested on the price-earnings ratio. The model is presented as follows:

$$
E P S=\beta_{0}+\beta_{1} T D R+\beta_{2} E T A+\beta_{3} S I Z E+\beta_{4} L Q+\beta_{5} T A N+\beta_{6} R O A+e
$$

Where,

$\beta_{0}$ is the constant term and $\beta$ is coefficient of variable

$\mathrm{ROA}=$ Return on assets

EPS=Earnings per share

$\mathrm{TDR}=$ Total debt ratio

$\mathrm{ETA}=$ Equity to total assets

LEV $=$ Leverage

SIZE $=$ Firm size

LQ=Liquidity

TAN=Assets tangibility

$\mathrm{e}_{\mathrm{it}}=$ Error term

\section{Variables and their measurement}

Return on assets measures how efficiently a company can manage its assets to produce profits during a period. It has been calculated as a percentage of net profit after tax divided by total assets. Earnings per share measure a firm's profitability by revealing how much profit a company generates with the money that shareholders have invested. It has been 
calculated as rupees of net profit available to shareholders divided by the number of shares outstanding. The total debt ratio measures the debt level of a business as a percentage of its total assets. It is calculated as the percentage of the total debt of a business divided by its total assets. Equity to total assets reveals capital adequacy and captures the general safety and soundness of the financial institution. It is calculated as the percentage of total equity to total assets.

The size of the firm is a factor that determines the company's base for financial performance and total corporate investment. It is calculated as an amount (rupees) of total assets in millions of rupees. Liquidity refers to the corporate capability to pay short term financial obligation. It is the ratio of current assets to current liabilities. The tangibility of assets is an important variable to describe investment in long term (fixed) assets out of total assets. It is calculated as the percentage of fixed assets to total assets.

Table 1

Variables, Notions and their Measurement

\begin{tabular}{lll}
\hline Variables & Notion & Measure \\
\hline $\begin{array}{l}\text { Dependent variables } \\
\text { Return on assets }\end{array}$ & ROA & (Net income / total assets) $\times 100$ \\
$\begin{array}{l}\text { Earnings per share }(\mathrm{Rs}) \\
\text { Independent variables }\end{array}$ & EPS & Net income /number of outstanding shares \\
$\begin{array}{l}\text { Total debt ratio } \\
\text { Equity to total assets }\end{array}$ & TDR & (Total debt / total assets $) \times 100$ \\
$\begin{array}{l}\text { Firm size } \\
\text { Liquidity ratio }\end{array}$ & ETA & (Equity/ total assets) $\times 100$ \\
Assets tangibility (percentage) & SIZE & Total assets of firms in millions of rupees \\
\hline
\end{tabular}

\section{Conceptual Framework}

This section provides the conceptual framework of the study and describes variables that have been used in the study and what study has assumed the relationship between the variables. The conceptual framework of this study includes the return on assets and earnings per share used as the dependents variables. Likewise, independent variables are total debt ratio, equity to total assets, firm size, liquidity ratio, and tangibility. The relationship between capital structure and firm performance is shown in Figure 1. The figure shows the capital structure variables and control variables used in this study to measure the impact on financial performance on Nepalese insurance companies. Capital structure is measured with the help of capital structure variables as total debt ratio (TDR) and equity to total assets (ETA) and control variables as firm size (SIZE), liquidity (LQ), and assets tangibility (TAN). Financial performance is measured with the help of two variables namely the return on assets (ROA) and earnings per share (Berger, 1995; Rajan \& Zingales, 1995; Sunder \& Myers, 1999; Zeitun \& Tian, 2007; Goyal, 2013; Singh \& Bagga, 2019). 


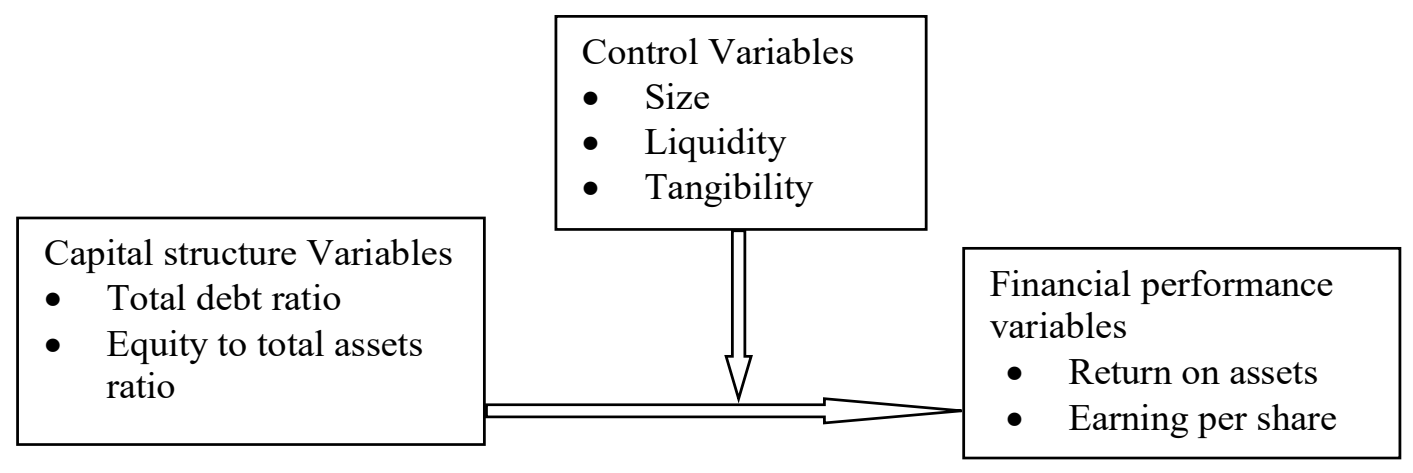

Figure 1. Schematic diagram of factors influencing financial performance of Nepalese insurance companies based upon the literature.

\section{RESULTS AND DISCUSSION}

Equity and debt are the sources of funds used by insurance companies for investment. The composition of equity and debt designed to invest in assets is capital structure. An optimal mix of these sources maximizes shareholders' equity. The position of capital structure and financial performance variables in the insurance industries of Nepal are presented and analyzed in this section.

Table 2

Position of Financial Performance and Capital Structure Variables (ROA, TDR and ETA in Percentage, EPS in rupees) Average for the Period 2013/14 to 2018/19

\begin{tabular}{lcccc}
\hline Panel A: Llife insurance companies & & & \\
\hline NAME OF COMPANY & ROA (\%) & EPS (RS) & TDR (\%) & ETA (\%) \\
SLICL & 2.39 & 4.69 & 30.64 & 69.36 \\
NLIC & 2.29 & 29.45 & 6.91 & 93.1 \\
NLICL & 1.5 & 21.91 & 5.89 & 94.11 \\
ALICL & 0.48 & 5.46 & 4.54 & 95.46 \\
GLICL & 0.66 & 5.37 & 13.42 & 86.58 \\
LICN & 0.85 & 23.99 & 5.22 & 94.78 \\
PLIC & 2.23 & 19.94 & 11.93 & 88.07 \\
Average & 1.49 & 15.83 & 11.22 & 88.78 \\
\hline Panel B: Nonlife insurance companies & & & \\
\hline HGI & 4.92 & 31.4 & 68.45 & 31.55 \\
SICL & 5.52 & 45.54 & 62.66 & 37.29 \\
UIC & 4.08 & 9.93 & 64.74 & 35.26 \\
PIC & 7.94 & 34.56 & 53.08 & 46.88 \\
SICL & 8.11 & 45.04 & 59.87 & 40.13 \\
PICL & 6.5 & 29.06 & 35.31 & 64.59 \\
PRIN & 7.41 & 30.19 & 52.86 & 47.14 \\
Average & 6.35 & 32.25 & 56.71 & 43.29 \\
\hline Panel C: Life and nonlife insurance companies & & & \\
\hline Average & 3.92 & 24.04 & 33.97 & 66.02 \\
\hline
\end{tabular}


Table 2 shows that the position of total debt ratio and equity to total assets ratio used by life insurance and non-life insurance companies for six years. The life insurance company SLICL having maximum debt (30.64 percent) earned a maximum return on assets (2.39 percent) and has the minimum earning per share (Rs 4.69). ALICL with minimum lowest debt ratio (4.54 percent) earned minimum (Rs 0.48) return on assets during the study period. The capital structure of life insurance companies is 11.22 percent debt and 88.78 percent equity. Return on assets of these companies ranges from 0.48 percent to 2.39 percent with an industry average of 1.49 percent. Earning per share of this industry is Rs 15.83 with the ranges of Rs 4.69 to Rs 29.45. NLIC has maximum earning per share (Rs 29.45) followed by LICN (Rs 23.99). There no consistency between the changing relationships between capital structure variables and financial performance variables among life insurance companies.

The capital structure position of non-life insurance companies of Nepal includes an average debt ratio of 56.71 percent and the equity ratio is 43.26 percent. Return on assets ranges from 4.08 percent to 8.11 percent with an average of 6.35 percent. Earning per share in this industry ranges from Rs 9.93 to 45.54 with an average of Rs 32.25 during the study period. Capital structure position in the whole insurance industry consists of 56.71 percent debt and 43.29 percent equity. The result of financial performance variables such as return on assets is 3.92 percent and earning per share. As indicated by the table changes in capital structure variables changes the financial performance in the whole insurance industry of Nepal.

Table 3

Annual Position of Financial Performance and Capital Structure Variables in Insurance Companies (ROA, TDR and ETA in Percentage, EPS in rupees)

\begin{tabular}{|c|c|c|c|c|c|c|c|}
\hline Variables & $2013 / 14$ & $2014 / 15$ & $2015 / 16$ & $2016 / 17$ & $2017 / 18$ & $2018 / 19$ & Average \\
\hline \multicolumn{8}{|c|}{ Life insurance companies } \\
\hline $\mathrm{ROA}$ & 2.31 & 1.03 & 1.56 & 1.64 & 1.23 & 1.13 & 1.48 \\
\hline EPS & 22.2 & 12.86 & 19.68 & 19.77 & 11.38 & 9.08 & 15.83 \\
\hline TDR & 8.93 & 7.22 & 15.74 & 16.12 & 6.79 & 12.52 & 11.22 \\
\hline ETA & 91.07 & 92.78 & 84.26 & 83.88 & 93.21 & 87.48 & 88.78 \\
\hline \multicolumn{8}{|c|}{ Non-life insurance companies } \\
\hline $\mathrm{ROA}$ & 6.9 & 7.59 & 3.13 & 6.63 & 7.48 & 6.39 & 6.35 \\
\hline EPS & 42.24 & 38.24 & 24.79 & 40.85 & 27.26 & 19.71 & 30.19 \\
\hline TDR & 56.87 & 60.61 & 67.65 & 59.76 & 52.41 & 42.94 & 56.71 \\
\hline ETA & 43.13 & 39.39 & 32.35 & 40.24 & 47.59 & 57.06 & 43.29 \\
\hline \multicolumn{8}{|c|}{ Life and non-life insurance companies } \\
\hline ROA & 4.61 & 4.31 & 2.34 & 4.13 & 4.36 & 3.76 & 3.92 \\
\hline EPS & 32.22 & 25.55 & 22.24 & 30.31 & 19.51 & 14.4 & 24.04 \\
\hline TDR & 32.9 & 33.92 & 41.69 & 37.94 & 29.6 & 27.73 & 33.96 \\
\hline ETA & 67.1 & 66.08 & 58.31 & 62.06 & 70.4 & 72.27 & 66.04 \\
\hline
\end{tabular}


Table 3 shows the annual average result of life insurance companies, non-life insurance companies, and the total insurance industry from the fiscal year 2013/14 to 2018/19. Capital structure variables: debt and equity are in a fluctuating position. The level of debt ranges maximum of 16.12 percent in 2016/17 and a minimum of 6.79 percent in 2017/18 with an average of 11.22 percent. Return on assets in the life insurance industry is a minimum of 1.03 percent in 2014/15 and a maximum of 2.31 percent in 2013/14 with an average of 1.48 percent. The range of ROA in nonlife insurance companies is 3.13 percent in $2015 / 16$ to a maximum of 7.59 percent in 2014/15 with an average of 6.35 percent. The average return on assets in the total insurance industry is 3.92 percent during the study period whereas the average earning per share is 24.04. The financial performance of the nonlife insurance industry is better than the life insurance industry of Nepal. The total debt ratio of the non-life insurance industry is greater than the life insurance industry during the study period.

\section{Descriptive Statistics}

Descriptive statistics of dependent variables and independent variables under study are presented in Table 5. Return on assets and return on equity are the dependent variables. Independent variables of the study are total debt ratio, equity to total assets ratio, size, liquidity, and tangibility. The results are based on 84 observations of 14 sample companies from the study period $2013 / 14$ to $2018 / 19$.

Table 4

Descriptive Statistics of Kew Variables

\begin{tabular}{lrrrrr}
\hline Variables & $\mathrm{N}$ & Minimum & Maximum & Mean & SD \\
\hline ROA & 84 & -20.83 & 18.62 & 3.97 & 4.78 \\
EPS & 84 & -85.67 & 84.88 & 24.15 & 22.10 \\
TDR & 84 & 2.15 & 90.45 & 33.32 & 27.92 \\
ETA & 84 & 3.74 & 97.85 & 66.68 & 27.67 \\
SIZE & 84 & 581.65 & 78383.62 & 10869.67 & 15434.45 \\
LQ & 84 & 0.26 & 26.1 & 4.81 & 5.12 \\
TAN & 84 & 0.32 & 16.07 & 3.03 & 3.07 \\
\hline
\end{tabular}

Table 4 indicates the position of financial performance as return on assets which ranges from negative 20.83 percent to 18.62 percentages leading to an average of 3.97 percent. Earnings per share vary from negative Rs 85.67 to a maximum of Rs 84.88 with an average of Rs 24.15. The position of capital structure variables such as total debt to total assets varies from 2.15 percent to 90.45 percent leading to an average of 33.32 percent and average equity to total assets ratio is 66.68 percent. Likewise, there is a great fluctuation in the size of the insurance companies which is minimum of Rs 581.65 million to maximum of Rs 78383.62 million with an average of Rs 10869.67 . The mean value of liquidity is 4.81 
with a maximum of 26.1 to a minimum of 0.26 . The ratio of tangible assets to total assets shows a maximum of 16.07 percent and a minimum of 0.32 percent with an average of 3.03 percent in the insurance industry of Nepal.

\section{Relationship Among Study Variables}

As per the indication of descriptive statistics, the Pearson correlation coefficients among the study variables are presented in Table 5 ROA and EPS are the dependent variables and TDR, ETA, SIZE, liquidity, and tangibility are independent variables. The first part of the table shows the correlation coefficients among the study variables of life and non-life insurance companies. The upper part of the diagonal relates to the correlation coefficients among variables of non-life insurance companies and the lower part of the diagonal relates to life insurance companies.

Table 5 shows that there is a positive correlation between ROA and EPS, TDR, and TAN. It means an increase in these variables' increases return on assets. The relationship of ROA with ETA, SIZE, and liquidity is negative that clarifies that an increase in these variables decreases ROA in the insurance industry of Nepal. The correlation coefficient of EPS with debt ratio and tangibility is a positive but negative relationship with ETA, SIZE, and liquidity. All the coefficients are significant at one percent level except the relationship between EPS and TDR which is significant at 5 percent level. Correlation coefficient EPS and SIZE and EPS and LQ are not significant.

Table 5

Pearson Correlation Coefficients among Dependent and Independent Variables

\begin{tabular}{lccccccc}
\hline Variables & ROA & EPS & TDR & ETA & SIZE & LQ & TAN \\
\hline ROA & 1 & & & & & & \\
EPS & $.749 * *$ & 1 & & & & & \\
TDR & $.361 * *$ & $.231^{*}$ & 1 & & & & \\
ETA & $-.316^{* *}$ & $-.300^{* *}$ & $-.911^{* *}$ & 1 & & & \\
SIZE & $-.319 * *$ & -0.058 & $-.505^{* *}$ & $.472 * *$ & 1 & & \\
LQ & $-.372^{* *}$ & -0.122 & $-.679 * *$ & $.478^{* *}$ & $.346^{* *}$ & 1 & \\
TAN & $.451 * *$ & $.383^{* *}$ & $.403^{* *}$ & $-.363^{* *}$ & $-.345^{* *}$ & $-.318^{* *}$ & 1 \\
\hline
\end{tabular}

Note. The asterisk signs (**) and (*) indicate that the results are significant at 1 percent and 5 percent level respectively.

\section{Effect of Cross-Sectional Variables on Financial Performance Indicators}

Having indicated the Pearson correlation coefficients, the regression analysis has been made and the results are presented. More specifically, it shows the impact of different cross-sectional variables on the performance indicators for the Nepalese insurance industry. First of all impact of the individual independent variable on the dependent variable has been presented then the impact of capital structure variables on dependent variables is presented. 
Finally, the impact of all the variables on financial performance has been presented. Normality was checked with the help of a normal P-P plot and found no outliers and data were normal. Multicollinearity was checked by calculating the variance inflation factor (VIF) that was less than 4. Autocorrelation was also tested with the help of the Durbin Watson test using SPSS that was 1.8 and 1.7 on return on assets and return on equity respectively. It justifies the minimum autocorrelation. Regression result from Model 1 to 5 shows the impact of the total debt ratio, equity to total assets ratio, size, liquidity, tangibility on return on assets and earning per share individually, Model 6 relates to the impact of EPS on ROA and ROA on EPS. Model 7 shows the impact of capital structure variables on return on assets and earnings per share, Model 8 shows the impact of control variables on return on assets and earnings per share. Finally, Model 9 shows the impact of all study variables on return on assets and earnings per share.

\section{Regression Result on Return on Assets}

Table 6

\section{Impact of Cross-Sectional Variables on Return on Assets}

The results are based on panel data of 14 Nepalese listed insurance Companies with 84 observations for the period of 2013/14 to 2018/19 by using the linear regression model. The model is $\mathrm{ROA}=\beta 0+$ $\beta_{1} T D R+\beta_{2} E T A+\beta_{3} S I Z E+\beta_{4} L Q+\beta_{5} T A N_{+} \beta_{6} E P S+e$. The cross-sectional variables used as independent variables are TDR (total debt ratio), ETA (equity to total assets ratio), SIZE (total assets in millions of rupees), LQ (ratio of current assets and current liabilities), TAN (tangible assets to total assets) and EPS (earning per share). The error term is represented as $e$. The dependent variable is ROA (return on assets).

\begin{tabular}{cccccccccc}
\hline Model & Intercept & TDR & ETA & SIZE & LQ & TAN & EPS & R2 & F Value \\
\hline 1 & $1.909^{*}$ & $0.062^{* *}$ & & & & & & 0.131 & $12.320^{* *}$ \\
& $(2.497)$ & $(3.510)$ & & & & & & & \\
2 & $7.524^{* *}$ & & $-0.055^{*}$ & & & & & 0.100 & $9.072^{*}$ \\
& $(5.875)$ & & $(-3.012)$ & & & & & & \\
3 & $5.054^{* *}$ & & & $-0.000^{*}$ & & & & 0.102 & $9.309^{* *}$ \\
& $(8.279)$ & & & $(-3.051)$ & & & & & \\
4 & $5.643^{* *}$ & & & & $-.348^{* *}$ & & & 0.139 & $13.188^{* *}$ \\
& $(8.418)$ & & & & $(-3.632)$ & & & & \\
5 & 1.836 & & & & & $0.704^{* *}$ & & 0.204 & $20.994^{* *}$ \\
& $(2.781)$ & & & & & $(4.582)$ & & & \\
6 & 0.060 & & & & & & $0.162^{* *}$ & 0.561 & $104.67^{* *}$ \\
7 & $(0.908)$ & & & & & & $(10.231)$ & & \\
7 & 0.611 & 0.074 & 0.014 & & & & & 0.132 & $6.142^{* *}$ \\
8 & $(0.146)$ & $(1.730)$ & $(0.315)$ & & & & & & \\
& $3.794^{* *}$ & & & -0.000 & $-0.206^{*}$ & $0.526^{* *}$ & & 0.275 & $10.116^{* *}$ \\
9 & $(4.001)$ & & & $(-1.202)$ & $(-2.122)$ & $(3.241)$ & & & \\
& -3.419 & 0.037 & 0.056 & $-0.00^{* *}$ & $-0.178^{*}$ & 0.090 & $0.160^{* *}$ & 0.700 & $29.957^{* *}$ \\
& $(-0.998)$ & $(1.043)$ & $(1.863)$ & $(-3.164)$ & $(-1.989)$ & $(0.781)$ & $(10.422)$ & & \\
\hline
\end{tabular}

Note. Figures in parentheses are t-values. The asterisk signs $(* *)$ and $(*)$ indicate that the results are significant at 1 percent and 5 percent level respectively. 
The result shows that the beta coefficients are negative for equity to total assets, size, and liquidity. This indicates that the ratio of equity, size, and liquidity impacts negatively on return on assets. This finding is similar to the finding of Khan and Mitra (2014). Beta coefficients are positive for debt ratio, tangibility, and earning per share. This indicates that an increase in total debt ratio, TAN, and EPS increase the return on assets. The finding is consistent with the results. Idle investment in assets and higher liquidity decrease the financial performance of the insurance industry in Nepal. A higher debt ratio and efficient investment in tangible assets increase the return on assets of insurance companies. The Fvalue of 29.957 is also significant at a $1 \%$ level of confidence indicates the fit of the model presented. $\mathrm{R}^{2}$ of .700 suggests that 70 percent of the financial performance can be explained by the variations in the whole set of independent variables.

\section{Regression Result on Earning Per Share}

This section discusses the result of the OLS regression model incorporating the Impact of the debt ratio, equity to total assets ratio, size, liquidity, tangibility, and return on assets on earnings per share.

\section{Table 7}

\section{Impact of Cross-Sectional Variables on Earnings Per Share}

The results are based on panel data of 14 Nepalese listed insurance Companies with 84 observations for the period of 2013/14 to 2018/19 by using the linear regression model. The model is EPS $=\beta 0+\beta_{1} T D R+$ $\beta_{2} E T A+\beta_{3} S I Z E+\beta_{4} L Q+\beta_{5} T A N_{+} \beta_{6} R O A+e$. The cross-sectional variables used as independent variables are TDR (total debt ratio), ETA (equity to total assets ratio), SIZE (total assets in millions of rupees), $L Q$ (ratio of current assets and current liabilities), TAN (tangible assets to total assets) and ROA (return on assets). The error term is represented as e. Dependent variable is EPS (earning per share).

\begin{tabular}{|c|c|c|c|c|c|c|c|c|c|}
\hline Model & Intercept & TDR & ETA & SIZE & LQ & TAN & ROA & $\mathrm{R} 2$ & F Value \\
\hline 1 & $\begin{array}{l}19.997^{* *} \\
(5.574)\end{array}$ & $\begin{array}{l}0.120 \\
1.552\end{array}$ & & & & & & 0.029 & 2.409 \\
\hline 2 & $\begin{array}{c}39.758^{* *} \\
(6.678)\end{array}$ & & $\begin{array}{l}-0.24 * * \\
(-2.846)\end{array}$ & & & & & 0.090 & $8.100^{* *}$ \\
\hline 3 & $\begin{array}{c}25.042 * * \\
(8.436)\end{array}$ & & & $\begin{array}{c}-0.000 \\
(-0.522)\end{array}$ & & & & 0.003 & 0.272 \\
\hline 4 & $\begin{array}{c}26.691^{* *} \\
(8.053)\end{array}$ & & & & $\begin{array}{c}-0.529 \\
(-1.117)\end{array}$ & & & 0.015 & 1.248 \\
\hline 5 & $\begin{array}{c}15.772 * * \\
(4.990)\end{array}$ & & & & & $\begin{array}{r}2.762 * * \\
(3.757)\end{array}$ & & 0.147 & $14.116^{* *}$ \\
\hline 6 & $\begin{array}{c}10.400^{* *} \\
(4.963)\end{array}$ & & & & & & $\begin{array}{c}3.963 * * \\
(10.231)\end{array}$ & 0.561 & $104.670 * *$ \\
\hline 7 & $\begin{array}{c}58.696^{* *} \\
(4.084)\end{array}$ & $\begin{array}{c}-0.197 \\
(-1.446)\end{array}$ & $\begin{array}{l}-0.43 * * \\
(-2.773)\end{array}$ & & & & & 0.113 & 5.149 \\
\hline 8 & $\begin{array}{l}14.341 \\
(3.027)\end{array}$ & & & $\begin{array}{c}0.000 \\
(0.803)\end{array}$ & $\begin{array}{c}-0.106 \\
(-0.217)\end{array}$ & $\begin{array}{c}2.932 \\
(3.617)\end{array}$ & & 0.122 & $4.843 * *$ \\
\hline 9 & $\begin{array}{c}29.474 * * \\
2.837\end{array}$ & $\begin{array}{l}-0.193 * \\
(-1.975)\end{array}$ & $\begin{array}{l}-0.36 * * \\
(-3.542)\end{array}$ & $\begin{array}{c}0.000 * * \\
(3.323)\end{array}$ & $\begin{array}{c}0.643 \\
(1.670)\end{array}$ & $\begin{array}{c}0.682 \\
(1.215) \\
\end{array}$ & $\begin{array}{c}3.674 \\
(10.523)\end{array}$ & 0.682 & $27.577 * *$ \\
\hline
\end{tabular}

Note. Figures in parentheses are t-values. The asterisk signs $\left(*^{*}\right)$ and $\left(^{*}\right)$ indicate that the results are significant at 1 percent and 5 percent level respectively. 
The beta coefficients are negative for ETA, SIZE, and liquidity. It implies that the impact of these variables on earning per share is negative. An increase in ETA, SIZE, and liquidity decreases the earning per share as an indicator of the financial performance of the total insurance industry. The beta coefficient of the total debt ratio, tangibility, and return on assets are positive that indicates an increase in debt ratio, tangibility, and return on assets increase earning per share. The F-value of 26.947 is also significant at one percent level of confidence indicates the fit of the model presented. $\mathrm{R}^{2}$ of 0.677 suggests that 67.70 percent of the earning per share can be explained by the variations in the whole set of independent variables.

\section{CONCLUSIONS}

The capital structure position of Nepalese life insurance companies consists of 11.22 percent of total debt and 88.78 percent equity financing. The ratio in the non-life insurance industry is 56.71 percent debt and 43.26 percent equity; the results are 33.97 percent and 66.02 percent respectively in the total insurance industry. Financial performance measures such as return on assets and earning per share are 1.49 percent and Rs 15.83 in the life insurance sector but the results in non-life insurance are 6.35percent and Rs 32.25. In the insurance industry of Nepal; the results are 3.92 percent and Rs 24.04 respectively.

In the Nepalese insurance industry, there is a positive impact of total debt ratio and assets tangibility on return on assets. This finding is consistent with the findings of Margaritis and Psillaki (2010), Haq, Nasir, Ahmad, Ali, and Ullah (2011), Zhang (2011), Mehari and Aemiro (2013) and Oziomobo et al. (2016). Hence, the insurance companies willing to increase return on assets can increase their total debt ratio and tangible assets. There is a negative impact of equity to total assets Size and liquidity on return on assets. This finding is similar to the findings of Trujillo-Ponce (2013), Wang (2002) and Dawood (2014). So the insurance companies willing to increase return on assets can decrease equity, firm size and liquidity ratio.

Beta coefficients are negative for ETA, SIZE, and liquidity on earning per share. It implies that there is a negative impact of these variables on earning per share. An increase in ETA, SIZE, and liquidity decrease earnings per share as the indicator of the financial performance in the Nepalese insurance industry. This finding is similar to the findings of Trujillo-Ponce (2013) and Dawood (2014). The beta coefficient of the total debt ratio, tangibility, and return on assets on earning per share are positive that indicates an increase in debt ratio, tangibility, and return on assets increase earning per share as financial performance. The result is consistent with Margaritis and Psillaki (2010), Nasir et al. (2011), and Oziomobo et al. (2016). 
The major conclusion of this study is that capital structure variables such as debt and equity and firm-specific variables such as size liquidity and tangibility are the major variables with a significant impact on the financial performance of the Nepalese insurance industry. The regression result further clarifies that the impact of operating results and firm-specific variables are more significant than the total debt ratio and equity to total assets ratio. The insurance companies of Nepal interested to increase financial performance can increase their total debt ratio and tangible assets and decrease equity, firm size, and liquidity ratio.

\section{REFERENCES}

Agiobenebo, T. J., \& Ezirim, B. C. (2002). Impact of financial intermediation on the profitability of insurance companies in Nigeria. First Bank of Nigeria Quarterly Review, 2(1), 4-14.

Ahmed, N., Ahmed, Z., \& Ahmed, I. (2010). Determinants of capital structure: A case of life insurance sector of Pakistan. European Journal of Economics, Finance and Administrative Sciences, 6(24), 7-12.

Basnet, A. (2015). Capital structure of financial firms: Evidence from Nepalese commercial banks (Unpublished master's thesis). Hanken School of Economics, Vaasa.

Berger, A. N. (1995). The relationship between capital and earnings in banking. Journal of Money, Credit and Banking, 27(1), 432-456.

Bhattarai, Y. (2016). Capital structure and firm performance: Evidence from Nepalese manufacturing companies. Journal for Studies in Management and Planning, 2(3), 138-150.

Chechet, I. L., \& Olayiwola, A. B. (2014). Capital structure and profitability of Nigerian quoted firms: The agency cost theory perspective. American International Journal of Social Science, 3(1), 139-158.

Dawood, U. (2014). Factors impacting profitability of commercial banks in Pakistan for the period of (2009-2012). International Journal of Scientific and Research Publications, 4,1-7.

Dogan, M. (2013). Does firm size affect the firm profitability? Evidence from Turkey. Research Journal of Finance and Accounting, 4(4), 53-59.

Idode, P. E., Adeleke, T. M., Ogunlowore, A. J., \& Ashogbon, O. S. (2014). Influence of capital structure on profitability: Empirical evidence from listed Nigerian banks. Journal of Business and Management, 16(11), 22-28.

Kaya, O. (2015). The effects of firm-specific factors on the profitability of non-life insurance companies in turkey. International Journal of Financial Studies, 3 (4), 510-529.

Kazempour, M., \& Aghaei, M. A. (2015). Capital structure and firms' performance in Tehran stock exchange. International Journal of Management, Accounting and Economics, 2(2), 149-152. 
Khan, G.S., \& Mitra, P. (2014). A causal linkage between FDI inflows with select macroeconomic variables in India - An econometric analysis. Journal of Economics and Finance, 5(5), 2321-5933.

Maharjan, A. (2017). Relationship between capital structure and profitability: A study of Nepalese commercial banks. Nepalese Journal Management, 4(2), 96-111.

Margaritis, D., \& Psillaki, M. (2010). Capital structure, equity ownership and firm performance. Journal of Banking and Finance, 34 (3), 621-632.

Modigliani, F., \& Miller, M. H. (1958). The cost of capital, corporation finance and the theory of investment. The American Economic Review, 48(3), 261-297.

Modigliani, F., \& Miller, M. H. (1963). Corporate income taxes and the cost of capital: A correction. American Economic Review, 53(4), 433-443.

Myers, S.C. (1977). Determinants of corporate borrowing. Journal of Financial Economics, 5(2), 147-175.

Opoku, E. F., Audu, J. K., \& Anarfi, B. O. (2013). The impact of capital structure and profitability of listed banks on the Ghana Stock Exchange. Social and Basic Sciences Review, 1(2), 74-91.

Poudel, R. B. (1994). Industrial finance in Nepal (Unpublished Ph. D. thesis), Tribhuvan University, Kathmandu, Nepal.

Pouraghajan, A. A., Tabari, Y., Ramezani, A., Mansourinia, E., Emmagho, M., \& Majd, P. (2012). Relationship between the cost of capital and accounting criteria of corporate performance evaluation: Evidence from Tehran Stock Exchange. World Applied Science Journal, 20(5), 666 - 673.

Pradhan, R. S., \& Shrestha, R. (2015). Impact of bank specific and macroeconomic variables on the performance of Commercial Banks of Nepal. Nepalese Journal of Business, 2(1), 73-84.

Rajan, R. G., \& Zingales, L. (1995). What do we know about capital structure? Some evidence from international data. The Journal of Finance, 50(5), 1421-1460.

Saad, N. M. (2010). Corporate governance compliance and the effects to capital structure. International Journal of Economics and Finance, 2(1), 105-114.

Saeedi, A., \& Mahmoodi, I. (2011). Capital structure and firm performance: Evidence from Iranian companies. International Research Journal of Finance and Economics, 70(7), 20-29.

Singh, N. P., \& Bagga, M. (2019) The Effect of Capital Structure on Profitability: An Empirical Panel Data Study. Jindal Journal of Business Research, 5(4). 1-13.

Sunder, L.S \& Myers, S.C. (1999). Testing static tradeoff against pecking order models of capital structure. Journal of Financial Economics, 51(2), 219-244. 
Taub, A. J. (1975). Determinants of the firm's capital structure. Review of Economics and Statistics, 57(5), 410-416.

Trujillo-Ponce, A. (2013), What determines the profitability of banks? Evidence from Spain. Accounting \& Finance, 53, 561-586. doi:10.1111/j.1467-629X.2011.00466.x.

Wang, Y. J. (2002). Liquidity management, operating performance, and corporate value: Evidence from Japan and Taiwan. Journal of Multinational Financial Management, 12(2),159-169. doi:10.1016/S1042-444x(01)00047-0

Wippern, R.F. (1966). Financial structure and the value of the firm. The Journal of Finance, 21(4), 615-633.

Yahyazadehfar, M., Shams, S., \& Larimi, J. (2010). The relationship between economic value added, ratio of profitability and market value added of companies listed at Tehran stock exchange. Accounting and Auditing Review, 59(8), 113-128.

Zeitun, R., \& Tian, G. G. (2007). Capital structure and corporate performance: Evidence from Jordan. Australasian Accounting Business and Finance Journal, 1(4), 40-61.

\section{Appendix I}

List of Insurance Companies Selected for the Study along with Symbol used and Nature

\begin{tabular}{rlll}
\hline SN & Insurance companies & Symbol used & Nature \\
\hline 1 & Asian Life Insurance Co. Limited & ALICL & Life Insurance \\
2 & Gurans Life Insurance Company Ltd & GLICL & Life Insurance \\
3 & Himalayan General Insurance Co. Ltd & HGI & Non-Life Insurance \\
4 & Life Insurance Corporation Limited & LIC & Life Insurance \\
5 & National Life Insurance Co. Ltd. & NALICL & Life Insurance \\
6 & Nepal Life Insurance Co. Ltd. & NLIC & Life Insurance \\
7 & Prabhu Insurance Ltd. & PICL & Non-Life Insurance \\
8 & Premier Insurance Co. Ltd. & PRIC & Non-Life Insurance \\
9 & Prime Life Insurance Company Limited & PMICL & Life Insurance \\
10 & Prudential Insurance Co. Ltd. & PUICL & Non-Life Insurance \\
11 & Sagarmatha Insurance Co. Ltd. & SGIC & Non-Life Insurance \\
12 & Shikhar Insurance Co. Ltd & SHICL & Non-Life Insurance \\
13 & Surya Life Insurance Company Limited & SLICL & Life Insurance \\
14 & United Insurance Co. (Nepal) Ltd. & UIC & Non-Life Insurance \\
\hline
\end{tabular}




\section{Appendix II}

Position of Capital structure and financial performance variables of sampled Insurance companies of Nepal during study periods

LIFE INSURANCE COMPANIES

\begin{tabular}{|c|c|c|c|c|c|c|c|c|}
\hline $\begin{array}{l}\text { Insurance } \\
\text { Companies }\end{array}$ & Year & $\mathrm{ROA} \%$ & EPS in Rs & TDR\% & ETA\% & Size in $\mathrm{m}$ & LQ(CA/CL) & TAN\% \\
\hline \multirow[t]{6}{*}{ SLICL Surya life } & $13 / 14$ & 2.93 & 8.21 & 6.58 & 93.42 & 1400.09 & 8.51 & 1.14 \\
\hline & $14 / 15$ & 0.89 & 3.41 & 9.82 & 90.18 & 1906.64 & 6.97 & 1.5 \\
\hline & $15 / 16$ & 4.28 & 3.77 & 152.11 & 55.67 & 1906.64 & 0.27 & 1.94 \\
\hline & $16 / 17$ & 5.18 & 6.63 & 104.61 & 38.01 & 3961.73 & 0.26 & 1.08 \\
\hline & $17 / 18$ & 2.15 & 2.76 & 10.95 & 88.52 & 5650.2 & 5.38 & 0.75 \\
\hline & $18 / 19$ & 2.68 & 3.8 & 9.85 & 90.15 & 7774.03 & 6.35 & 0.79 \\
\hline \multirow[t]{6}{*}{ NLIC Nepal life } & $13 / 14$ & 6.12 & 56.67 & 11.31 & 88.69 & 10040.17 & 0.57 & 3.35 \\
\hline & $14 / 15$ & 0.67 & 10.36 & 4.92 & 95.08 & 27010.23 & 15.2 & 1.23 \\
\hline & $15 / 16$ & 2.5 & 41.83 & 4.61 & 95.39 & 36311.15 & 15.64 & 0.88 \\
\hline & $16 / 17$ & 2.02 & 33.03 & 6.78 & 93.22 & 50750.87 & 8.76 & 0.62 \\
\hline & $17 / 18$ & 2.33 & 33.06 & 7.88 & 92.12 & 62356.27 & 4.83 & 0.49 \\
\hline & $18 / 19$ & 0.67 & 9.52 & 5.93 & 94.07 & 78383.62 & 5.37 & 0.39 \\
\hline \multirow[t]{6}{*}{ NLICL National } & $13 / 14$ & 2.12 & 32.21 & 6.62 & 93.38 & 11887.19 & 11.53 & 5.17 \\
\hline & $14 / 15$ & 1.86 & 25.88 & 5.69 & 94.31 & 14192.35 & 13.72 & 4.6 \\
\hline & $15 / 16$ & 2.05 & 26.4 & 5.43 & 94.57 & 17038.17 & 12.67 & 3.86 \\
\hline & $16 / 17$ & 0.94 & 17.78 & 5 & 77.79 & 24950.86 & 9.27 & 2.62 \\
\hline & $17 / 18$ & 1 & 18.02 & 5.7 & 80.52 & 29972.9 & 7.34 & 2.13 \\
\hline & $18 / 19$ & 1 & 11.18 & 6.9 & 93.1 & 33656.67 & 5.26 & 1.88 \\
\hline \multirow[t]{6}{*}{ ALICL Asian life } & $13 / 14$ & 0.47 & 5.6 & 14.12 & 85.88 & 6159.87 & 1.99 & 1.18 \\
\hline & $14 / 15$ & 0.3 & 3.07 & 2.15 & 97.85 & 6931.87 & 10.03 & 1.86 \\
\hline & $15 / 16$ & 1.11 & 12.31 & 2.5 & 97.5 & 8952.9 & 7.81 & 2.36 \\
\hline & $16 / 17$ & 0.37 & 5.23 & 2.7 & 97.3 & 11338.69 & 7.51 & 1.99 \\
\hline & $17 / 18$ & 0.31 & 3.66 & 2.64 & 97.36 & 15071.39 & 4.32 & 1.49 \\
\hline & $18 / 19$ & 0.29 & 2.9 & 3.14 & 96.86 & 20023.55 & 5.56 & 1.22 \\
\hline \multirow[t]{6}{*}{ GLICL Gurans } & $13 / 14$ & 0.5 & 3.22 & 3.55 & 51.92 & 3195.05 & 26.1 & 0.74 \\
\hline & $14 / 15$ & 0.72 & 3.44 & 8.69 & 91.31 & 2401.39 & 10.22 & 1.18 \\
\hline & $15 / 16$ & 0.12 & 0.67 & 6.8 & 93.2 & 3195.05 & 13.95 & 0.77 \\
\hline & $16 / 17$ & 1 & 7.04 & 7.3 & 92.7 & 4190 & 2 & 0.53 \\
\hline & $17 / 18$ & 1.04 & 9.63 & 6.51 & 93.49 & 5502.74 & 2 & 0.65 \\
\hline & $18 / 19$ & 0.57 & 8.22 & 47.66 & 52.34 & 13501.48 & 1.97 & 0.32 \\
\hline \multirow[t]{6}{*}{ LICN Life ins Corp } & $13 / 14$ & 1.13 & 29.6 & 4.14 & 95.86 & 17239.86 & 14.61 & 1.28 \\
\hline & $14 / 15$ & 1.1 & 29.11 & 4.77 & 95.23 & 22585.46 & 16.07 & 0.97 \\
\hline & $15 / 16$ & 1.1 & 30.06 & 4.19 & 95.81 & 29288.88 & 16.68 & 0.75 \\
\hline & $16 / 17$ & 1.27 & 36.18 & 6.22 & 93.78 & 37912.21 & 5.46 & 0.61 \\
\hline & $17 / 18$ & 0.23 & 8.17 & 5.24 & 94.76 & 47849.94 & 4.54 & 0.49 \\
\hline & $18 / 19$ & 0.27 & 10.81 & 6.78 & 93.22 & 60803.48 & 5.48 & 0.43 \\
\hline \multirow[t]{6}{*}{ PLIC Prime life } & $13 / 14$ & 2.91 & 19.92 & 16.19 & 83.81 & 3341.14 & 4.35 & 3.61 \\
\hline & $14 / 15$ & 1.69 & 14.77 & 14.49 & 85.51 & 4271.15 & 5.41 & 2.78 \\
\hline & $15 / 16$ & 2 & 22.75 & 13.41 & 86.59 & 5540.17 & 5.88 & 2.1 \\
\hline & $16 / 17$ & 2.24 & 32.53 & 11.52 & 88.48 & 7081.27 & 4.01 & 1.56 \\
\hline & $17 / 18$ & 2.11 & 12.12 & 8.58 & 91.42 & 10261.06 & 5.81 & 1.13 \\
\hline & $18 / 19$ & 2.4 & 17.54 & 7.39 & 92.61 & 13021.66 & 5.02 & 0.89 \\
\hline
\end{tabular}




\section{NON-LIFE INSURANCE COMPANIES}

\begin{tabular}{|c|c|c|c|c|c|c|c|c|}
\hline $\begin{array}{l}\text { Insurance } \\
\text { Companies }\end{array}$ & Year & $\mathrm{ROA} \%$ & EPS(RS) & TDR $\%$ & ETA $\%$ & Size in $m$ & $\mathrm{LQ}(\mathrm{CA} / \mathrm{CL})$ & TAN\% \\
\hline \multirow[t]{6}{*}{ HGI Himalayan } & $13 / 14$ & 8.06 & 37.34 & 60.98 & 39.02 & 1158.49 & 1.28 & 3.34 \\
\hline & $14 / 15$ & 7.99 & 52.96 & 67.43 & 32.57 & 1774.23 & 1.28 & 2.16 \\
\hline & $15 / 16$ & 1.84 & 39.85 & 90.45 & 9.55 & 6954.17 & 0.99 & 0.58 \\
\hline & $16 / 17$ & 1.54 & 25.57 & 88.17 & 11.83 & 6411.91 & 0.98 & 0.68 \\
\hline & $17 / 18$ & 3.22 & 13.74 & 65.59 & 34.41 & 4380.97 & 1.3 & 1.09 \\
\hline & $18 / 19$ & 6.87 & 19.33 & 38.07 & 61.93 & 2887.85 & 2.13 & 2.29 \\
\hline \multirow{7}{*}{$\begin{array}{l}\text { SICL } \\
\text { Sagarmatha }\end{array}$} & & & & & & & & \\
\hline & $13 / 14$ & 1.01 & 65.54 & 5.52 & 3.74 & 20023.55 & 17.89 & 0.43 \\
\hline & $14 / 15$ & 3.13 & 21.05 & 65.98 & 34.02 & 2400.58 & 1.39 & 3.65 \\
\hline & $15 / 16$ & 5.21 & 46.98 & 75.43 & 24.57 & 3982.18 & 1.26 & 2.16 \\
\hline & $16 / 17$ & 7.37 & 50.8 & 66.89 & 33.11 & 3710.51 & 0.9 & 5.22 \\
\hline & $17 / 18$ & 9.4 & 61.84 & 56.44 & 43.56 & 3543.28 & 1.45 & 5.87 \\
\hline & $18 / 19$ & 6.99 & 27.62 & 51.6 & 48.4 & 3954.94 & 1.62 & 5.17 \\
\hline \multirow[t]{6}{*}{ UIC United } & $13 / 14$ & 6.43 & 55.21 & 71.68 & 28.32 & 865.54 & 1.18 & 3.7 \\
\hline & $14 / 15$ & 0.42 & 4.33 & 74.19 & 25.81 & 1047.01 & 1.23 & 2.75 \\
\hline & $15 / 16$ & -20.83 & -85.67 & 81.72 & 18.28 & 1243.91 & 1.16 & 2.5 \\
\hline & $16 / 17$ & 18.62 & 84.88 & 65.57 & 34.43 & 1378.21 & 1.33 & 2.49 \\
\hline & $17 / 18$ & 12.64 & 0.52 & 49.55 & 50.45 & 1254.77 & 1.74 & 2.27 \\
\hline & $18 / 19$ & 7.18 & 0.3 & 45.73 & 54.27 & 1282.44 & 1.8 & 1.82 \\
\hline \multirow[t]{6}{*}{ PIC Primier } & $13 / 14$ & 6.15 & 39.05 & 63.87 & 36.13 & 744.54 & 1.29 & 10.7 \\
\hline & $14 / 15$ & 11.31 & 45.63 & 51.15 & 48.85 & 1160.09 & 1.53 & 6.87 \\
\hline & $15 / 16$ & 11.94 & 49.42 & 51.71 & 48.29 & 1546.67 & 1.66 & 5.36 \\
\hline & $16 / 17$ & 8.05 & 34.75 & 53.58 & 46.42 & 1935.98 & 1.55 & 4.66 \\
\hline & $17 / 18$ & 3.04 & 15.63 & 49.58 & 50.42 & 3007.4 & 1.71 & 2.85 \\
\hline & $18 / 19$ & 7.17 & 22.86 & 48.56 & 51.44 & 3426.88 & 1.72 & 2.75 \\
\hline \multirow[t]{6}{*}{ SICL Shikhar } & $13 / 14$ & 9.52 & 44.04 & 57.45 & 42.55 & 1378.06 & 1.28 & 16.07 \\
\hline & $14 / 15$ & 11.79 & 61.4 & 57.11 & 42.89 & 1863.35 & 1.3 & 11.38 \\
\hline & $15 / 16$ & 3.45 & 36.06 & 72.31 & 27.69 & 5329.84 & 1.22 & 8.4 \\
\hline & $16 / 17$ & 5.19 & 40.91 & 72.08 & 27.92 & 6450.52 & 1.24 & 7.51 \\
\hline & $17 / 18$ & 8.55 & 43.09 & 57.14 & 42.86 & 5325.47 & 1.4 & 10.58 \\
\hline & $18 / 19$ & 10.17 & 44.73 & 43.11 & 56.89 & 4649.12 & 1.78 & 5.24 \\
\hline \multirow[t]{6}{*}{ PICL Prabhu } & $13 / 14$ & 6.73 & 32.03 & 56.15 & 43.85 & 869.5 & 1.44 & 12.2 \\
\hline & $14 / 15$ & 8.57 & 32.67 & 48.96 & 51.04 & 1119.32 & 1.53 & 8.96 \\
\hline & $15 / 16$ & 11.74 & 45.18 & 43.38 & 56.62 & 1266.43 & 1.81 & 7.73 \\
\hline & $16 / 17$ & 1.7 & 28.53 & 5.88 & 94.12 & 9677.5 & 2.39 & 0.98 \\
\hline & $17 / 18$ & 9.3 & 33.35 & 29.07 & 70.93 & 2468.94 & 2.92 & 3.76 \\
\hline & $18 / 19$ & 0.96 & 2.61 & 28.44 & 71.56 & 2742.03 & 2.94 & 3.27 \\
\hline \multirow[t]{6}{*}{ PRIN Prudential } & $13 / 14$ & 10.42 & 22.44 & 28.38 & 71.62 & 581.65 & 2 & 3.75 \\
\hline & $14 / 15$ & 9.92 & 50.03 & 59.48 & 40.52 & 1361.77 & 1.41 & 2.28 \\
\hline & $15 / 16$ & 8.53 & 41.71 & 58.52 & 41.48 & 1743.77 & 0.95 & 1.55 \\
\hline & $16 / 17$ & 3.92 & 21.13 & 66.15 & 33.85 & 2303 & 0.82 & 1.63 \\
\hline & $17 / 18$ & 6.24 & 25.29 & 59.53 & 40.47 & 2597.73 & 0.89 & 1.43 \\
\hline & $18 / 19$ & 5.4 & 20.53 & 45.09 & 54.91 & 2438.42 & 1.79 & 1.34 \\
\hline
\end{tabular}

